УДК 323.21(477)+061.2:0604+17.022.1

DOI: 10.24144/2078 -1431.2020.1(24).65-73

Маріан Токар,

кандидат історичних наук, доцент, доцент кафедри похітології і державного управління ДВНЗ «Ужгородський національний університет»

\title{
ДО ПИТАННЯ ПРОБЯЕМ МІЖНАРОДНОГО ІМІДЖУ СУЧАСНИХ УКРАЇНСЬКИХ ГРОМАДСЬКИХ ОРГАНІЗАЦІЙ
}

У статті розкрито питання міжнародного іміджу сучасних громадських організацій в Україні. Акцентовано увагу на динаміці їхнього розвитку, публічній активності і співпраці з міжнародними інституціялми. Виділено фази та причини активізації публічної діяльності громадських організацій. Наведено приклади сучасних проблем та особливостей в їхній діяльності, що впливають на їхній міжнародний імідж. Підкреслено мотиваційну складову діяльності організацій, що зосереджена переважно у просвітницькій сутності їхньої роботи, пропаганді демократичних цінностей, відродженні «волонтерського духу».

Ключові слова: громадські організації, міжнародні зв'язки, гранти, співпрацяя, іміджева історія.

During the years of Ukraine's independence, the procedure of propaganda of democratic values among the local population and provability of all their advantages for nation-building has grown quite significantly. The key role in this process was played by the citizens themselves, who made a confident choice in favor of the general democratic evolution of the state at the turn of the 1980's and 1990's. New Ukraine has since tried not to change this strategic course. However, the hybridity of some of the ruling political regimes is constantly testing the strength of the democratic vaccination of the Ukrainian nation. Time has shown that this strength can be traced to the example of the activities of national non-governmental organizations in state-building and public administration processes. Using the experience of Euro-Atlantic partners, national associations of citizens, which in the spirit of their program activities are aimed at community service, have acted as generators of propaganda for the whole spectrum of democratization of society. A significant part of public organizations, which are essentially called to be motivated missionaries and mediators of cultural and educational training of all members of a democratic society, were given the opportunity to spread democratic values among the citizens of Ukraine at various levels.

Undoubtedly, all these facts affect the international image of the state and civil society in Ukraine in general. Even despite the negative phenomena «rooted» in the modern democratic model of state development, including those inherited by the communist-Soviet administration (corruption, non-publicity of power, interethnic and national relations, etc.), the level of social readiness for value self-improvement is constantly growing. In addition, the local «third sector» is assisted by international support in the form of dissemination of various grant and other assistance programs, strategies, 
courses, etc. Ukrainian society, through representatives of public organizations, adequately responds to such opportunities for cooperation and is involved in the public development of potential opportunities in practice. Such activity of public organizations, foundations, associations is a positive example of improving the international image of Ukraine, which can not but please all parties to the relevant public interaction.

The problem of public actualization of public organizations in Ukraine is closely connected with international support and affects the international image of Ukrainian public organizations, which, at the same time, serve as a kind of measure of democracy and publicity of civil society in Ukraine.

Keywords: public organizations, international relations, grants, cooperation, image history.

Постановка проблеми. За роки незалежності України досить відчутно зростала процедура пропаганди серед місцевого населення демократичних цінностей і доказовість усіх їхніх переваг для національного державотворення. Ключову роль у цьому процесі відіграли самі громадяни, котрі зробили упевнений вибір на користь загальнодемократичної еволюції держави на здамі 1980-х - 1990-х років. Нова Україна $з$ того часу намагаеться не змінювати цей стратегічний курс. Щоправда, гібридність деяких правлячих політичних режимів щоразу випробовуе міцність демократичної вакцинації української нації. Час показав, що цю міцність можна відслідковувати на прикладі діяльності національних неурядових громадських організацій у державотворчих і публічно-управлінських процесах. Завдяки використанню досвіду євроатлантичних партнерів національні об'єднання громадян, які за духом своєї програмної діяльності спрямовані до суспільно-корисної роботи, виступили генераторами пропаганди всього спектру демократизації суспільства. Значна частина громадських організацій, що за своєю суттю покликані бути вмотивованими місіонерами і посередниками культурно-освітнього вишколу всіх членів демократичного суспідьства, отримади можливість на різних рівнях поширювати демократичні цінності серед громадян України.

Аналіз останніх досліджень і публікацій. Проблеми міжнародного іміджу громадських організацій хоч і знаходяться на поверхні сучасних публічно-управлінських відносин, усе ж дише частково знаходять відображення в українській джерельній базі. Тому ми послуговувалися тими матеріалами, які наводять на думку про проблемні аспекти й необхідність науково-дослідницької реакції на їх вирішення. Насамперед нашу увагу привернули статті, що по-різному розкривають наближені до мети нашої дослідницької проблеми. Тому, розмірковуючи з приводу тих чи інших аспектів, ми відштовхувалися від матеріалів, авторами яких є Н. Гаєва [1], С. Іщук [3], П. Мороз [4]. У нашому дослідженні ми послуговувадися й змістом офіційних документів [5-6], і опублікованими результатами авторських досліджень [7-8].

Мета статті - візуалізувати проблеми міжнародного іміджу сучасних громадських організацій України. Безумовно, названі вище у постановці проблеми статті факти впливають загалом на міжнародний імідж держа- 
ви та громадянського суспільства в Україні. Навіть незважаючи на «вкорінені» в сучасну демократичну модель державного розвитку негативні явища, серед яких такі, що залишилися у спадок комуно-радянським управлінням (корупція, непублічність влади, міжетнічні й національні відносини тощо), рівень суспільної готовності до ціннісного самовдосконалення постійно зростає. Крім того, на допомогу місцевому «третьому сектору» приходить міжнародна підтримка у вигдяді поширення різноманітних грантових та інших допоміжних програм, стратегій, курсів тощо. Українське суспільство через представників громадських організацій адекватно реагує на таку мождивість співпраці й залучається до публічного освоєння потенційних мождивостей на практиці. Така активність громадських організацій, фондів, об'єднань є позитивним прикладом підвищення міжнародного іміджу України, що не може не тішити всі сторони відповідної публічної взаємодії. На цьому й акцентується увага у розрізі досягнення завдань і мети дослідження.

Резудьтати дослідження. Наголосимо на тому, що значного зростання міжнародний імідж українського громадянського суспідьства відцув у постпомаранчеві часи (від 2005 р.), і не в останню чергу завдяки подадышій актуалізації суб'єктності громадських організацій. Саме тоді почав свій відлік «частково-інституційний» етап розвитку громадських організацій в Україні [7, с. 130]. На нашу думку, саме впродовж 2006 - 2012 років стали відчутними регенерація проявів класичного громадянського суспідьства, вихід інституцій держави і громадянського суспільства на конструктивний публічний діалог, правове коригування спеціалізованого (цільового) законодавства в напрямі адаптації його до вимог європейських і світових демократичних норм.

Як показуе час, щоразу нові спроби державної влади вплинути на контроль над «третім сектором» приводять до того, що громадянське суспільство, відчуваючи «просторовий голод», розпочинає активну фазу публічного самозахисту й активізує свою природну колективну діяльність. Це особливо проявилося під час Помаранчевої революції та у перші роки після неї. Громадяни відчули, що громадські організації справді можуть виступати центрами захисту й реалізації їхніх публічних прав і свобод, потреб та інтересів на засадах спідьної громадської мотивації. Відповідно активізувалася й інтелігенція та наукова спільнота України, які зініціювали публічну дискусію з владою з приводу подальшого місця й ролі громадянського суспільства i, зокрема громадських організацій у сучасних суспільно-політичних процесах [8].

Разом із тим, активна фаза публічної взаємодії влади та громадськості, наслідком чого став загальнонаціональний процес складання регіональних цільових програм, сприяла розвитку громадянського суспільства та співпраці органів публічної влади і структур громадянського суспільства [3]. Ця публічна активність пожвавила інтерес до суспільно-політичних процесів в Україні з боку міжнародних інституцій, провідну роль серед яких зайняли міжнародні фонди, діяльність яких була спрямована на сприяння демократичному розвитку України та громадянського суспідь- 
ства в ній. Активною формою співпраці таких інституцій з громадськими організаціями України стала, зокрема, грантова робота.

Попри те, що за період 2009 - 2012 років правдяча влада частково «приспала» масово-публічну активність громадських організацій, значна частина останніх занурилася у грантову діяльність. Це мало два взаємовигідні наслідки. Перший - міжнародні фонди отримали прямий вплив на інтелектуально-діяльнісний потенціал українських громадських організацій та можливість через їхні структури втілювати різноманітні прояви демократичної ідеології. Друге - громадські організації отримади чи не єдиний шанс, не порушуючи свої статутні приписи, поліпшити матеріально-технічну базу й уперше публічно себе позиціонувати в середовищі громадянського суспільства як суспільно-корисна інституція.

Тим часом українська правляча влада формально діяла подвійними стандартами й, з одного боку, пішла на згортання публічного контактування 3 громадянським суспільством, 3 другого - на вимогу європейських партнерів консолідувала роботу в напрямі вироблення державної політики сприяння розвитку громадянського суспільства в Україні, розробки конкретних першочергових заходів щодо їі реалізації [6]. Все ж це мало позитивні наслідки, оскільки заключна фаза цього етапу ознаменувалася прийняттям Верховною Радою України та підписанням Президентом України 22 березня 2012 року Закону України «Про громадські об'єднання». До цього часу цей етап розвитку громадських організацій в Україні залишився в історії завдяки кільком правкам від 2005 (ст. 205, ст. 550); 2006 (ст. 215), 2008 (ст. 240), 2009 (ст. 485), 2010 (ст. 496), 2011 (ст. 41) років [5].

Міжнародна підтримка боротьби українців не тільки за демократизацію, а й за незалежність України особливим чином проявилася в наступні роки. Трагічні події кінця 2013 - початку 2014 років дали старт новому етапу в динаміці розвитку громадських організацій України - «активістсько-волонтерського». Хронологічно він охоплює період від початку 2013 року до кінця 2015 року. Революція Гідності сприяла відродженню «духу волонтерства» в діяльності громадських організацій, що на новий рівень публічного сприйняття підняв категорію «громадська організація». У змісті роботи останніх почали проявлятися модерні публічно-управдінські види (соціально-медичні послуги, креативна індустрія, розвиток місцевих громад тощо). Узагалі публічну активність громадських організацій на цьому етапі можна розділити на дві змістові частини. Перша частина - «активістська-суспільна» - пов'язана з уведенням у дію в січні 2013 року Закону України «Про громадські об'єднання», який визначає правові та організаційні засади реалізації права на свободу об'єднання, гарантованого Конституцією України та міжнародними договорами України, згода на обов'язковість яких надана Верховною Радою України, порядок утворення, реєстрації, діяльності та припинення діяльності громадських об'єднань [5]. Незважаючи на чисельні поправки, цей правовий документ сформулював більш-менш чіткі визначення та межі публічного функціонування громадських організацій в Україні. Можна вважати, що цей закон став результатом еволюції суспільно-подітичних погдядів представників 
публічної влади і громадянського суспільства, впливу міжнародних експертів, а на думку деяких дослідників - «істотно змінив концептуальні засади конституційного права на свободу об'єднання (ст. 36 Конституції України)» [1, с. 94]. Чітке визначення формулювання «громадська організація», яке з'явилося у цій редакції закону, активізувало громадян до прояву активної автономної громадянської позиції. Найголовніше, що в Законі України чітко розмежовано статусну форму громадських організацій від політичних партій, вказано на «географію» об'єднань національного та міжнародного статусу й узаконено самоуправлінську суть i непідконтродьність органам державної влади.

Друга частина публічної активності громадських організацій на цьому етапі - «волонтерсько-масова» - стала прямим наслідком Революції Гідності та початком військової окупації Російською Федерацією східних регіонів України (частина Донецької та Дуганської областей), анексією АР Крим і, відповідно, масштабним громадським піднесенням українського народу в напрямі не тільки психологічно-моральної, а й матеріально-фінансової допомоги національній армії (3СУ) та добровольчим загонам. Це сприяло публічній активізації громадського ресурсу на створення відповідних соціальних умов розвитку свободи особистості та різноманітності демократично-діяльнісних проявів. Значна кількість громадських організацій у тій чи іншій мірі була залучена до волонтерського руху, що сприяло підняттю авторитету «третього сектора» як в Україні, так і на міжнародній арені й надало значного поштовху розвитку громадянського суспільства та змісту публічно-управдінських відносин.

Разом із тим, «волонтерсько-масова» фаза цього етапу неабияк посприяла динамічному перетіканню в «інституційно-внормовану фазу» нового етапу - «суспільно-інституційного», початок якого відносимо до 2016 року. Наступний етап характеризується тим, що громадські організації почали брати активнішу участь у структуруванні простору суспільно-корисних інституцій, готових до публічної взаємодії з ключовими «акторами» держави і громадянського суспільства. Але найцінніший здобуток цього етапу - набуття громадськими організаціями практики інституціалізаційної діядьності [7, с. 134]. Поступово частіше представники громадських організацій почали брати участь у процесах ініціювання обговорення, подання та прийняття законодавчих актів, впливати на регулювання і контроль кадрових призначень, реалізації антикорупційних програм, вдосконалення публічно-управлінських відносин, а також координації здійснення реформ на всіх рівнях публічного управління. Цей етап є незавершеним і продовжуеться в наші дні.

Іншими словами, динаміка розвитку громадських організацій в Україні, реформа децентралізації влади 3 іi публічно-управлінським змістом, творення громад, перегляд пріоритетних завдань інституцій громадянського суспільства у напрямі першочерговості суспільно-корисної дії та соціально орієнтованої праці вказує на добрі перспективи досягнення синергетичного ефекту на шляху виконання державотворчих завдань усіма суб'єктами публічно-управлінських відносин. Відтак громадські орга- 
нізації виступають важливою синергетичною ланкою таких процесів, і не в останню чергу завдяки підтримці міжнародних партнерів.

Виходячи 3 вищенаведеного, слід підкреслити, що на кількісне і якісне зростання мережі громадських організацій в Україні за останні роки особливим чином вплинули зарубіжні грантодавці - міжнародні благодійні фонди та громадські організації, дипломатичні, державні та громадські установи демократичних країн Европи (не членів ЕС), Европейського Союзу, США та Канади. Під їхнім патронатом відбулося неабияке стимулювання «третього сектора» в Україні (матеріально-фінансове, кадрово-інтелектуальне, тематично-просвітницьке та ін.). Значна частина діючих до цього і новостворених громадських організацій зайняла просвітницько-пропагандистський простір громадянського суспільства, підтримуючи демократичні цінності в Україні, практику захисту прав та свобод громадян, апробацію публічно-управлінських та інформаційно-технологічних інновацій.

Постреволюційні кризові явища в публічній політиці часто-густо відображаються на загадьному розвитку громадянського суспільства. Вони можуть мати різноманітне вираження. Проте одним із найнебезпечніших iз них у демократичних державах стає порушення балансу публічної взаємодії та комунікації між основними суб'єктами публічно-управдінських відносин. Сьогодні одним із таких комунікаторів слід вважати й національні громадські організації, які водночас виступають і індикаторами рівня міжнародного іміджу України. Звісно, ще залишається проблема психологічного зламу свідомості громадян у питаннях публічно-управдінських відносин. Існує й низка інших проблем. Що ж до мотиваційної діяльності українських громадських організацій на сучасному етапі, то можна вирізнити кілька сутнісних проблем (особливостей), що постають у контексті негативних особливостей організаційно-управлінського спектру поширення демократичних цінностей в Україні й, відповідним чином, впливають на міжнародний імідж представників громадянського суспільства в Україні.

По-перше, є значний ризик здовживання національними громадськими організаціями в напрямі «грантоїдства» [4]. Ця суспідьно-інституціональна «хвороба» постала з інституційних мождивостей грантової діяльності та свідомого потурання «духу волонтерства» окремими громадськими об'єднаннями, які створювалися як механізм заробляння коштів на актуальних суспільних темах і проблемах. Донорські інституції, серед яких є державні й недержавні установи, дипломатичні місії, громадські корпорації та союзи проводять відповідний моніторинг неурядових організацій, постійно змінюють умови конкурсного відбору потенційних партнерів, добре обізнані в життедіяльності тих чи інших інституцій громадянського суспільства в Україні, формують так звані «чорні списки» «недобросовісних» організацій тощо. Серед останніх позитивних нововведень 3 боку грантових донорів щодо залучення громадських організацій партнерами фінансованих програм можемо назвати введення обмежень на вік організаціі (не менше 5-ти років діяльності), обов'язкова наявність дієвого партнера в зоні ЄС та інституційна біографія з наявністю інформації про 
участь у подібних конкурсах в минулому. На думку грантодавців, такий підхід вказуе на якість надання відповідних послуг цільовій групі грантової програми, вдосконалення практичних навиків учасників («акторів»), використання набутого досвіду в подальшій роботі, а найголовніше - унеможливлюе потрапляння грантів до рук «нечесних» або «тіньових» громадських організацій і псевдоактивістів.

По-друге, в Україні існують прецеденти неадекватного лобіювання деякими органами державної влади та органами місцевого самоврядування своїх приватних інтересів. Як правило, це відбувається шляхом формалізованого пошуку партнерів, непублічного проведення конкурсу та недемократичної процедури відбору громадських організацій, прихованої змови між суб'єктами грантової діяльності. У цьому разі грантодавці розраховують винятково на совість учасників грантової програми й забезпечення успішної іï результативності. Насамперед лобіювання інтересів грантової програми виражається в недопущенні до відкритого конкурсу конкурентів умовно «своїх» громадських організацій тощо. Це також є проявом негативної форми «грантоїдства», що впливає на авторитет публічної влади, довіру партнерів у вирішенні важливих питань місцевого значення, міжнародний імідж громадських організацій і держави загалом.

По-трете, самі неурядові організації ситуативно ставляться до вирішення наявних у державі та суспільстві проблем. Мова не йде про інституції громадянського суспільства, які створені з метою подолання якої-небудь «профільної» проблеми. Візьмемо, до прикладу, умовну громадську організацію, що за статутними цілями займається гендерною проблематикою і відповідно бере участь у грантовій програмі з питань подолання гендерної дискримінації та інших подібних проявів в українському суспільстві [2]. Відповідно мережу громадських організацій такого комплексу дій можна розділити на дві групи.

Перша - це неурядові громадські організації, які створюються безпосередньо носіями гендерних цінностей і легалізуються на основі пропаганди гендерної рівності в суспільстві, визначають це як основний меседж своєї роботи. Як правило, грантова діяльність таких громадських організацій зосереджена винятково на питаннях гендеру та навколо нього. Такі організації тісно співпрацюють з подібними собі організаціями, можуть об'єднуватися 3 ними в організаційні коаліції, громадські корпорації чи союзи, є постійними партнерами донорських інституцій, які виносять у пріоритет дослідницько-пропагандистської діяльності гендерні дослідження тощо.

Другу групу становлять громадські організації транссекторадьного характеру, тобто такі, які за змістом своєї діяльності виконують різноманітні завдання демократично-ціннісної сфери, а гендерне питання в їхній діяльності не є пріоритетним, актуалізується ситуативно, винятково у разі виникнення програмної потреби, отримання відповідного тематичного гранту, залучення організації до роботи як тимчасового або постійного партнера і таке інше. Подібна практика є поширеною, адже грантодавці зацікавлені в розширенні «гендерної аудиторії» (у цьому прикладі), 
пошуку зацікавлених партнерів, ініціативних і креативних акторів тощо. Хоча загалом це більше особливість такої участі, а не негативна проблема.

Висновки і перспективи подадьших досліджень. Отже, бачимо, що проблема публічної актуалізації громадських організацій в Україні тісно пов' язана з міжнародним супроводом і впливає на міжнародний імідж українських громадських організацій, які водночас виконують функцію своєрідного мірила демократичності та публічності громадянського суспільства в Україні.

Попри те, що мотиваційна складова діяльності громадських організацій зосереджена переважно у просвітницькій сутності їхньої роботи, пропаганді демократичних цінностей, поширенні серед громадян культури взаємоповаги, рівності, справедливості, відродження «волонтерського духу» прищепляе громадянам відчуття соціальної відповідальності та публічної активності.

Відтак наголосимо, що сьогодні слід змінювати застаріле позиціонування громадських організацій, які часом є замкнутими і локалізованими об'єднаннями громадян, і досліджувати аспекти публічності їхньої діяльності. Це є вимогою міндивого часу, який виносить на порядок денний вмотивоване застосування публічно-управлінських інновацій у різних сферах суспільного буття. Цінність людини дедаді більше стає центричною, а принцип гуманізму актуалізуе завдання загальнолюдського виживання, що скеровуе до консолідації громадянського суспільства. Тому активна позиція національних громадських організацій у питанні захисту демократичних цінностей матиме відчутні позитиви на міжнародній арені, що сприятиме сприйняттю України у світі як сучасної повноправної демократичної держави.

\section{СПИСОК ВИКОРИСТАНИХ ДЖЕРЕ}

1. Гаєва Н. П. Критичний аналіз Закону України «Про громадські об’єднання»: деякі міркування // Часопис Київського університету права. 2013. № 4. С. 91-95.

2. Громадські організації. Організації та ініціативи // Гендер в деталях. URL: https:// genderindetail.org.ua/community/organizations/gromadski-organizatsii-134539. html (дата звернення: 03.11.2018).

3. Іщук С.І. Концептуадьні засади реалізації права на свободу об'єднань в Україні // Часопис Національного університету «Острозька академія». 2012. № 2 (6). Серія «Право». URL: http://lj.oa.edu.ua/articles/2012/n2/12isiovu.pdf (дата звернення: 20.02.2020).

4. Мороз П. «Третій сектор» по-українськи: гранітоїди чи суспільні діячі? //Цензор. нет. URL:https://censor.net.ua/blogs/1104799/tretyi_sektor_poukranski_grantodi_ chi_suspln_dyach (дата звернення: 02.11.2018).

5. Про громадські об'єднання: Закон України від 22 березня 2012 р. № 4572-VI // Законодавство України. URL: http:// zakon5.rada.gov.ua/ laws/show/4572-17 (дата звернення: 26.03.2020).

6. Про Стратегію державної політики сприяння розвитку громадянського суспільства в Україні та першочергові заходи щодо ії реалізації: Указ Президента України від 24 березня 2012 р. № 212/2012 // Законодавство України. URL: https://zakon. rada.gov.ua/laws/show/212/2012 (дата звернення: 07.05.2020). 
7. Токар М. Громадські організації України в системі розвитку публічно-управлінських відносин: монографія / Львівський регіональний інститут державного управління НАДУ при Президентові України. Дьвів: ЛРІДУ НАДУ, 2020. 412 с.

8. Токар М. Ю. Поетапний аналіз динаміки розвитку громадських організацій у контексті взаємодії держави і громадянського суспільства // Демократичне врядування: наук. вісн. Вип. 22 / за заг. ред. чл.-кор. НАН України В. С. Загорського, доц. А. В. Ліпенцева. Львів: ЛРІДУ НАДУ, 2018. URL: www.dv.lvivacademy.com (дата звернення: 21.02.2020).

\section{REFERENCES}

1. Haieva, N. P. (2013). Krytychnyj analiz Zakonu Ukrainy "Pro hromadski obiednannia": deiaki mirkuvannia [Critical analysis of the Law of Ukraine "On Public Associations": some considerations]. Chasopys Kyyivs'koho universytetu prava - Journal of Kyiv University of Law, 4, 91-95 [in Ukrainian].

2. Hromadski orhanizatsii. Orhanizatsii ta initsiatyvy [NGOs. Organizations and initiatives]. Gender v detaliakh. Retrieved from https://genderindetail.org.ua/community/organizations/gromadski-organizatsii-134539.html [in Ukrainian].

3. Ishchuk, S.I. (2012). Kontseptualni zasady realizatsii prava na svobodu obiednan v Ukraini [Conceptual principles of realization of the right to freedom of association in Ukraine]. Retrieved from http://li.oa.edu.ua/articles/2012/n2/12isiovu.pdf [in Ukrainian].

4. Moroz, P. "Tretij sektor" po-ukrainsky: hrantoidy chy suspilni diiachi? ["Third Sector" in Ukrainian: granitoids or public figures?]. Tsenzor.net. Retrieved from https://censor.net. ua/blogs/1104799/tretyi_sektor_poukranski_grantodi_chi_suspln_dyach [in Ukrainian].

5. Pro hromadski orhanizatsii [About public associations]. (2012) Zakon Ukraiiny vid 22 bereznia 2012 r. № 4572-VI. Zakonodavstvo Ukrainu. Retrieved from http:// zakon5. rada.gov.ua/ laws/show/4572-17 [in Ukrainian].

6. Pro Stratehiiu derzhavnoi polityky spryiannia rozvytku hromadianskoho suspilstva v Ukraini ta pershocherhovi zakhody shodo ii realizatsii [On the Strategy of State Policy to Promote the Development of Civil Society in Ukraine and Priority Measures for Its Implementation]. (2012). Ukaz Prezydenta Ukrainy vid 24 bereznia 2012 r. № 212/2012. Retrieved from https://zakon.rada.gov.ua/laws/show/212/2012 [in Ukrainian].

7. Tokar, M. (2020). Hromadski orhanizatsii Ukrainy v systemi rozvytku publichno-upravlinskykh vidnosyn [Public organizations of Ukraine in the system of development of public-administrative relations]. Lviv: LRIDU NADU [in Ukrainian].

8. Tokar, M. Yu. (2018). Poetapnyj analiz dynamiky rozvytku hromadskykh orhanizatsij u konteksti vzaiemodii derzhavy i hromadianskoho suspilstva [Step-by-step analysis of the dynamics of development of public organizations in the context of interaction between the state and civil society]. Demokratychne vriaduvannia: naukovyi VisnykDemocratic governance: a scientific bulletin, 22. Retrieved from www.dv.lvivacademy. com [in Ukrainian]. 